\title{
Meningkatkan Kualitas Pelayanan Perpustakaan melalui Kerja Sama antar Perpustakaan
}

\author{
Isti Suratmi ${ }^{1}$ \\ ${ }^{1}$ UPT Perpustakaan Institut Seni Indonesia Yogyakarta \\ Jalan Parangtritis km. 6,5 Yogyakarta \\ HP.: 085228108501; Email: istisuratmi79@gmail.com
}

\begin{abstract}
Abstrak
Perpustakaan merupakan salah satu lembaga penyedia informasi. Untuk itu perpustakaan harus mampu menyediakan informasi yang dibutuhkan oleh pemustakanya. Perpustakaan juga harus meningkatkan layanannya agar kebutuhan informasi pemustaka dapat terpenuhi, mengingat kebutuhan informasi pemustaka yang semakin kompleks dan beragam. Untuk menjaga dan meningkatkan kepuasan pemustaka atas layanan perpustakaan maka berbagai hal dapat diupayakan termasuk menjalin kerja sama dengan perpustakaan. Dengan adanya kerja sama ini memungkinkan pemustaka untuk dapat mengakses informasi yang dimiliki perpustakaan lain dan sumber informasi di luar perpustakaannya. Melalui kerjasama ini akan saling melengkapi dan lebih dapat memenuhi kebutuhan informasi pemustakanya.

Kata kunci: perpustakaan; layanan; kerja sama antar perpustakaan
\end{abstract}

\begin{abstract}
Improving the Quality of Library Services through Collaboration between Libraries. Library is one of the institutions providing information. For this, the library must be able to provide the information needed by the library. The library must also improve its services so that the information needs of the library can be met, given the increasingly complex and diverse information needs of the library. To maintain and increase the satisfaction of the library for library services, various things can be pursued including establishing cooperation with the library. This partnership allows the library to access information that other libraries have and sources of information outside their libraries. Through this cooperation will complement each other and be better able to meet the information needs of the library.
\end{abstract}

Keywords: library; service; cooperation between libraries

\section{A. Pendahuluan}

Kemajuan ilmu pengetahuan dan teknologi telah membawa perubahan besar dalam kehidupan umat manusia. Berbagai kemajuan tersebut juga memberikan dampak pada dunia perpustakaan. Perpustakaan sebagai penyedia informasi dan pemustaka sebagai pengguna informasi menjadikannya ibarat dua sisi mata uang yang saling berhubungan yang tak dapat terpisahkan. Hubungan atau keterkaitan ini dapat terwujud manakala perpustakaan dapat memberikan informasi yang memadai, sementara pemustaka mampu atau mau memahami, menghayati dan memaknai pentingnya informasi dalam kesehariannya (Cahyadi et al., 2021: 6). Sebagai pusat sumber informasi, perpustakaan akan berusaha memberikan layanan yang terbaik dalam memenuhi kebutuhan informasi untuk penggunanya. Agar tidak ditinggalkan oleh 
penggunanya, perpustakaan harus menyesuaikan diri dengan memberikan layanan yang bersifat aktif dengan menawarkan berbagai bentuk informasi kepada penggunanya. Namun pemenuhan kebutuhan informasi untuk pemustaka dinilai tidaklah mudah. Bagaimanapun suatu perpustakaan tidak akan mampu menyediakan semua kebutuhan penggunanya. Tuntutan pemustaka yang tinggi, sumber informasi yang semakin beragam dan kompleks, dan keterbatasan dana menyebabkan perpustakaan tidak dapat memenuhi semua kebutuhan dan keinginan pemustaka sehingga dalam layanan perpustakaan tidak dapat memberikan layanan prima dan capaian untuk memberikan kepuasan bagi pemustakanya jauh dari harapan. Salah satu cara untuk mengatasi permasalahan ini adalah melalui kerja sama dengan perpustakaan lain atau sumber informasi lain di luar perpustakaannya. Diharapkan dengan adanya kerja sama antar perpustakaan, perpustakaan dapat meningkatkan layanannya karena sebesar apapun perpustakaan belum tentu dapat memenuhi kebutuhan penggunanya. Dalam penulisan ini akan dibahas mengenai bentuk-bentuk kerjasama layanan antar perpustakaan dan faktor-faktor yang mempengaruhinya.

\section{B. Hasil dan Pembahasan}

Pelayanan perpustakaan merupakan ujung tombak dalam jasa penyelenggaraan perpustakaan, karena bagian inilah yang paling banyak berhubungan dengan penggunanya. Citra dan keberhasilan perpustakaan dalam menjalankan fungsinya ditentukan oleh kinerja layanan perpustakaan kepada pemustakanya. Layanan perpustakaan merupakan layanan yang mempertemukan langsung antara pustakawan dengan pemustakanya (Wahyuntini \& Endarti, 2021: 5). Pemustaka menginginkan untuk mendapatkan layanan yang baik. Kepuasan pemustaka merupakan target utama yang harus dicapai dalam layanan perpustakaan. Unsur utama layanan perpustakaan antara lain: fasilitas pelayanan perpustakaan, bahan pustaka yang tersedia, pemustaka, dan petugas pelayanan.

Pada hakikatnya pelayanan perpustakaan adalah membantu memenuhi kebutuhan informasi pemustaka dengan menyediakan bahan pustaka dan alat penelusurannya. Apabila memungkinkan perpustakaan juga bisa memberikan rujukan pada pemustaka jika informasi yang dibutuhkan tidak ada di perpustakaan. Menurut Rahayu (2015: 1.3) hakikat layanan perpustakaan adalah memberikan jasa informasi pada pemustaka yang berkaitan dengan: (1) Adanya bahan pustaka yang dibutuhkan pemustaka; (2) Adanya alat penelusuran informasi yang digunakan untuk menelusur informasi yang dicari pemustaka, baik yang ada di perpustakaan maupun di luar perpustakaan. Sedangkan tujuan layanan perpustakaan di samping agar bahan pustaka yang ada di perpustakaan dapat digunakan dengan optimal, juga agar kebutuhan informasi pemustaka dapat terpenuhi. Sementara fungsi layanan perpustakaan sebagai penghubung antara bahan pustaka dengan pemustaka yang membutuhkan. Adapun fungsi layanan perpustakaan antara lain: fungsi informasi dan penelitian, fungsi rekreasi, fungsi kebudayaan, fungsi pendidikan, fungsi deposit dan fungsi pelestarian bahan pustaka.

Berbagai jenis layanan tersedia di perpustakaan. Jenis layanan yang disediakan oleh perpustakaan bergantung pada jenis, tujuan, dan kemampuan perpustakaan dalam menyediakan berbagai jenis layanan. Ada beberapa faktor yang mempengaruhi, seperti tenaga perpustakaan yang profesional, ketersediaan dana untuk operasional pelayanan, dan kebutuhan pemustaka. Secara garis besar layanan yang ada di perpustakaan ada dua, yaitu layanan teknis dan layanan pembaca. Layanan teknis berkaitan dengan persiapan sebelum bahan pustaka disajikan, mulai dari pengadaan, pengolahan, dan pelestarian bahan pustaka. Sedangkan layanan pembaca adalah layanan yang berhubungan dengan pelayanan jasa perpustakaan. Layanan ini antara lain: layanan sirkulasi, layanan referensi/rujukan, layanan terbitan berkala, layanan pendidikan pemustaka, layanan penelusuran, layanan multimedia, layanan fotokopi, layanan peminjaman antar perpustakaan, dan sebagainya.

Sebagai lembaga/institusi yang bergerak dalam bidang pelayanan publik, perpustakaan berkewajiban untuk memberikan layanan yang terbaik agar pemustaka merasa puas. Namun 
adakalanya perpustakaan tidak dapat memenuhi kebutuhan penggunanya, dikarenakan sumber daya yang terbatas. Untuk itulah diperlukan kerja sama dengan perpustakaan lain. Dengan adanya kerja sama, perpustakaan tidak perlu membeli semua buku dan jurnal yang terbit. Menurut Sulistyo Basuki (1993: 54) kerja sama antar perpustakaan artinya kerja sama yang melibatkan dua perpustakaan atau lebih. Kerja sama diperlukan karena tidak ada satu pun perpustakaan yang dapat berdiri sendiri dalam arti koleksinya mampu memenuhi kebutuhan informasi penggunanya. Adanya kerja sama ini memberikan peluang pada pemustaka agar bisa mendapatkan informasi secara luas, dan pemustaka bisa berhubungan dengan perpustakaan dan pemustaka dari perpustakaan lain. Dengan demikian, secara individu kerja sama juga dapat terbentuk. Bagi perpustakaan, dengan adanya kerja sama ini bisa meningkatnya keterpakaian koleksi yang ada setiap perpustakaan anggota kerja sama (Suwarno, 2017: 1.8).

Berbagai alasan melatarbelakangi terbentuknya kerja sama antar perpustakaan, seperti: adanya ledakan informasi, kebutuhan informasi yang semakin meningkat, dan dana perpustakaan yang terbatas. Hal ini membuat perpustakaan tidak bisa memenuhi kebutuhan pengguna dengan hanya menyediakan koleksi yang dihimpun masingmasing perpustakaan. Menurut Sulistyo Basuki (1993: 54) banyak hal yang mendorong kerja sama antar perpustakaan, seperti: (1) Adanya peningkatan luar biasa dalam pengetahuan dan membawa pengaruh semakin banyak buku yang ditulis tentang pengetahuan tersebut; (2) Meluasnya kegiatan pendidikan, mulai dari sekolah dasar hingga ke perguruan tinggi mendorong semakin banyak dan beranekanya permintaan pemakai yang dari hari ke hari semakin banyak memerlukan informasi; (3) Kemajuan dalam bidang teknologi dengan berbagai dampaknya terhadap industri dan perdagangan serta perlunya pimpinan serta karyawan mengembangkan keterampilan dan teknik baru; (4) Berkembangnya kesempatan dan peluang bagi kerja sama internasional dan lalu lintas internasional; (5) Berkembangnya teknologi informasi, terutama dalam bidang komputer dan telekomunikasi, memungkinkan pelaksanaan kerja sama berjalan lebih cepat dan lebih mudah bahkan mungkin lebih murah; (6) Tuntutan masyarakat untuk memperoleh layanan informasi yang sama; (7) Kerja sama menungkinkan penghematan fasilitas, biaya, tenaga manusia, dan waktu. Dari berbagai alasan tersebut, dapat ditarik kesimpulan mengapa perpustakaan perlu bekerja sama. Perpustakaan tidak ada satu pun perpustakaan yang bisa memenuhi kebutuhan informasi pemakainya. Menurut Rahayu (2015: 8.5), ada beberapa bentuk kerja sama antar perpustakaan yaitu:

1. Kerja Sama Pengadaan

Sumber pengadaan bahan pustaka bisa dari pembelian, hadiah atau sumbangan, dan tukar menukar. Dorongan kerja sama dalam pengadaan bahan pustaka ini dikarenakan banyaknya buku yang diterbitkan dari berbagai ilmu pengetahuan. Masing-masing anggota kerja sama bertanggung jawab atas kebutuhan informasi penggunanya.

2. Kerja Sama Pertukaran dan Redistribusi Pertukaran dan redistribusi dapat digunakan untuk menambah koleksi perpustakaan. Kerja sama pertukaran dilakukan melalui pertukaran publikasi lembaga induk perpustakaaan tersebut dengan perpustakaan lain anggota kerja sama. Sedangkan kerja sama redistribusi dilakukan dengan menempatkan buku-buku yang tidak lagi digunakan di suatu perpustakaan ke perpustakaan lain.

3. Kerja Sama Pengolahan

Kerja sama pengolahan bahan pustaka biasanya dilakukan pada perpustakaan universitas (pusat) dengan perpustakaan fakultas atau perpustakaan umum dengan cabang-cabangnya. Pengolahan bahan pustaka menjadi tanggung jawab perpustakaan koordinator kerja sama.

4. Kerja Sama Penyediaan Fasilitas

Perpustakaan yang melakukan kerja sama menyediakan fasilitas berupa kesempatan menggunakan koleksi dan jasa perpustakaan seperti penelusuran informasi, informasi kilat, layanan fotokopi, tetapi tidak diperbolehkan untuk meminjam.

5. Kerja Sama Pinjam Antar Perpustakaan Dalam hal ini perpustakaan meminjamkan bahan pustaka dari perpustakaan lain anggota kerja 
sama. Selanjutnya perpustakaan meminjamkan kepada pemakainya. Dan yang bertanggung jawab terhadap peminjaman bahan pustaka tersebut adalah perpustakaan yang meminjam.

6. Kerja Sama Antar Pustakawan

Kerja sama dilakukan oleh pustakawan anggota kerja sama. Bentuk kerja sama ini seperti penerbitan buku panduan untuk pustakawan, pertemuan antar pustakawan, bimtek dibidang pusdokinfo untuk pustakawan dan lain-lain.

7. Kerja Sama Penyusunan Katalog Induk Perpustakaan yang melakukan kerja sama bersama-sama membuat katalog induk. Katalog ini memuat keterangan bahan pustaka yang dimiliki perpustakaan anggota kerja sama disertai keterangan lokasi keberadaan bahan pustaka.

8. Kerja Sama Pemberian Jasa Informasi (Silang Layan)

Silang layan merupakan kerja sama antara dua perpustakaan atau lebih dalam pemberian jasa informasi. Kerja sama seperti jasa penelusuran, jasa referal (temu balik informasi), jasa referens, pinjam antar perpustakaan, jasa fotokopi dan pengiriman dokumen.

Kerja sama antar perpustakaan memiliki banyak keuntungan bagi anggotanya. Menurut Suwarno (2017: 1.14) keuntungan yang dapat diperoleh melalui kerja sama antar perpustakaan, antara lain:

\section{Pemanfaatan Koleksi}

Kegiatan yang dapat dilakukan dalam pemanfaatan koleksi seperti: (1) memberikan akses silang informasi kepada perpustakaan anggota atau silang layang, seperti bantuan penelusuran, menyediakan fasilitas bagi anggota perpustakaan lain, pinjam antar perpustakaan, dan pengiriman dokumen; (2) layanan fotocopy bahan pustaka.

2. Berbagi Alat Penelusuran Informasi

Pemustaka anggota kerja sama bisa menelusur informasi menggunakan alat temu kembali seperti daftar bibliografi, katalog, daftar majalah yang dilanggan, daftar tambahan koleksi dan alat temu kembali lainnya.

3. Berbagi Pengetahuan dan Pengalaman

Dengan melakukan kerja sama memungkinkan pustakawan untuk berbagi pengetahuan dan pengalaman antar anggota. Sedangkan bagi pemustaka, lebih pada pengembangan studinya dan relasi sosialnya.

4. Pengembangan Keterampilan

Melalui kerja sama, pustakawan dapat berbagi peran sesuai keahliannya agar bisa diterapkan pada perpustakaannya, sehingga perpustakaan anggota kerja sama dapat maju dan berkembang bersama.

Dalam melakukan kerja sama tidak selamanya berjalan seperti yang diharapkan. Ada berbagai hambatan dan kendala dihadapi oleh perpustakaan manakala ingin membentuk suatu kerja sama. Menurut Purwono (2011: 3.35) berbagai hambatan tersebut seperti: (1) Ada kalanya anggota kerja sama menggunakan bahasa yang berbeda yang tentunya akan menimbulkan kesulitan dalam berkomunikasi; (2) Perpustakaan belum menyediakan anggaran untuk kerja sama, misalnya anggaran untuk penelusuran, pengiriman bahan pustaka, dan sebagainya; (3) Sikap perpustakaan, di mana banyak perpustakaan besar yang enggan melakukan kerja sama dengan perpustakaan yang lebih kecil; (4) Faktor geografi terlebih untuk daerah yang luas; (5) Adanya kekacauan politik di suatu negara, sehingga sulit diajak kerja sama karena negara lain takut kalau terjadi perubahan politik yang akan menghambat kerja sama; (6) Minimnya sarana dan prasarana yang dapat menunjang kelancaran komunikasi di antara anggota kerja sama; (7) Lemah koleksi, dikarenakan dana yang terbatas, membuat perpustakaan tidak dapat membangun koleksi yang memadai; (8) Minimnya tenaga profesional dibidang perpustakaan; (9) Kurang dipahaminya manfaat kerja sama. Banyak perpustakaan maupun lembaga induk yang kurang memberi dukungan dalam pelaksanaan kerja sama; (10) Kurang adanya informasi antar perpustakaan. Kurangnya pertukaran informasi antar perpustakaan sehingga masing-masing tidak mengetahui keadaan dan perkembangan perpustakaan lain; (11) Perbedaan peraturan fotokopi yang berkaitan dengan hak cipta; (12) Belum adanya kesamaan peraturan/ sistem.

Di samping berbagai hal di atas, agar kerja sama dapat berjalan lancar, diperlukan sarana 
penunjang. Berbagai macam sarana bantu kerja sama antar perpustakaan antara lain:

1. Katalog

Katalog merupakan wakil suatu dokumen yang berfungsi sebagai sarana temu kembali informasi. Katalog diperlukan sebagai petunjuk koleksi yang dimiliki perpustakaan anggota kerja sama. Untuk saat ini sebagian besar perpustakaan sudah terotomasi sehingga katalog sudah berbentuk online dapat diakses kapanpun dan dimanapun. Hal ini akan memudahkan dalam penelusuran informasi.

2. Bibliografi

Bibliografi adalah daftar buku atau artikel majalah, biasanya untuk subjek tertentu. Tujuan dibuatnya bibliografi adalah membantu pemakai dalam menentukan lokasi keberadaan suatu bahan pustaka.

3. Katalog induk

Katalog induk dibuat oleh dua perpustakaan atau lebih, digunakan sebagai sarana mengetahui lokasi bahan perpustakaan untuk pinjam antarperpustakaan. Jadi pada katalog induk selalu ada lokasi yang menunjukkan di mana lokasi buku tersebut.

4. Katalog induk majalah

Katalog induk majalah adalah katalog majalah dari dua perpustakaan atau lebih yang melakukan kerja sama. Katalog ini disusun menurut abjad judul majalah. Adanya katalog induk majalah memudahkan mengetahui lokasi majalah yang dicari.

5. Indeks

Indeks ini memuat entri berita dalam majalah/ surat kabar yang disusun secara sistematis untuk memudahkan temu balik informasi yang dicari.

6. Abstrak

Abstrak merupakan suatu ringkasan dari suatu artikel ilmiah. Abstrak digunakan sebagai sarana kerja sama untuk menelusur artikel yang diminta seorang pemakai, dan mencegah adanya artikel yang dibuatkan abstrak berulang.

Adanya berbagai sarana bantu kerja sama tersebut dapat memudahkan pustakawan maupun pemustaka dalam menemukan kembali informasi yang dibutuhkan secara cepat dan tepat.

\section{Kesimpulan dan Saran}

Sebagai lembaga pelayanan yang berorientasi pada pemustaka, perpustakaan selalu berupaya untuk dapat memberikan layanan terbaik, agar dapat memenuhi kebutuhan pemustaka. Kepuasan pemustaka merupakan indikator utama bagi keberhasilan perpustakaan sebagai penyedia dan pengelola informasi. Namun adakalanya perpustakaan tidak dapat memenuhi kebutuhan penggunanya. Hal ini dikarenakan keterbatasan sumber daya yang dimiliki oleh perpustakaan. Untuk itulah diperlukan kerja sama dengan perpustakaan lain. Dengan adanya kerja sama ini, memperluas akses pemustaka ke sumber informasi milik perpustakaan lain yang melakukan kerja sama. Namun dalam melakukan kerja sama adakalanya menemui berbagai kendala dan hambatan seperti: bahasa, biaya, sikap perpustakaan, geografi, politik, dan lain sebagainya. Untuk mengatasi hal tersebut hendaknya perpustakaan yang akan melakukan kerja sama mempertimbangkan hal-hal tersebut sehingga kerja sama dapat berjalan dengan baik.

\section{Kepustakaan}

Cahyadi, I. N., Hartono, F. L. A., \& Sriwahyudewi, I. 2021. Peranan Perpustakaan dalam Meningkatkan Prestasi Belajar Mahasiswa Pascasarjana ISI Yogyakarta. ABDI PUSTAKA: Jurnal Perpustakaan Dan Kearsipan, 1(1), 7-14.

Purwono. 2011. Materi Pokok Kerja Sama dan Jaringan Perpustakaan. Universitas Terbuka.

Rahayu, L. 2015. Materi Pokok Layanan Perpustakaan. Universitas Terbuka.

Sulistyo, B. 1993. Pengantar Ilmu Perpustakaan. Gramedia Pustaka Utama.

Suwarno, W. 2017. Materi Pokok Jaringan Kerja Sama Perpustakaan dan Informasi. Universitas Terbuka.

Wahyuntini, S., \& Endarti, S. 2021. Tantangan Digital dan Dinamisasi Koleksi Dalam Pemanfaatan Koleksi Perpustakaan Bagi Prestasi Belajar Mahasiswa. ABDI PUSTAKA: Jurnal Perpustakaan Dan Kearsipan, 1(1), 1-6. 